\title{
SOCIALISM A GREAT TURNING POINT IN HUMAN HISTORY
}

Yumna Khatoon ${ }^{*}$

\begin{abstract}
The $20^{\text {th }}$ century is the aeon for the social and national liberation of the individual. Freedom is a boon and basic right of every individual's existence. Human freedom is infringed by certain social and economic order. This research paper undertakes the task to reveal the reasons behind the pandemonium of humankind living in capitalism; the basic fact for the rise and development of socialism around the globe. This paper is divided into six parts. Part I is introduction. Part II deals with historical need to replace capitalism by socialism. Part III explores the economic decisive factors in capitalism. Part IV explores the economic decisive factors in socialism. Part V leads to threats of neo-colonialism. Part VI is conclusion. This research finally leads to the conclusion that socialism is the system for the abolition of regime of exploitation created by capitalism. It aims at transforming a just society based upon principles of equality, fraternity, democracy and fair play.
\end{abstract}

Keywords: Socialism, capitalism, communist, neo-colonialism, democracy, fair play

\section{Introduction}

It is difficult to say when and where volcanic magma of socialism erupted first. Many social scientists held the view that Plato's "Republic" is the first evidence of socialism. According to Brian R. Nelson the marrow of the Republic is to be found in social justice for people within states. ${ }^{1}$

Plato stated in the Republic unless....political power and philosophy meet together....there can be no rest from troubles....for states, nor.....For all mankind....2 Whereas some social scientists ponder to reveal the fact that history of socialism is traceable to Bible particularly to the Old Testament. Christian teachings preached and practiced socialism in everyday life and repelled from the concept of "Mine and Thine." Christianity and Platonism are imbibed in Thomas Moore's Utopia (1516). It has been aptly called "the first monument of modern socialism." He has borrowed the idea from Plato's Republic and from St. Augustine's the city of God. Utopia recommends collective ownership and use of property. More glorifies the spirit of tolerance, justice, equality, peace and happiness in Utopia. All the virtues he portrayed in his work are basic elements for socialist state. If we turn the pages of history we will be aware of the fact that from the Middle Ages to the $16^{\text {th }}$ century the age of Renaissance and the

\footnotetext{
*Yumna Khatoon, Lecturer English Department, Federal Urdu University, Abdul Haq Campus, Karachi

${ }^{1}$ Western political thought, $2^{\text {nd }}$ edition, pp.25-26

${ }^{2}$ The republic of Plato, pp.1-14
} 
Reformation, strong protest was recorded based on hoarding of wealth. Various communist or socialist sects germinated in England during civil war (1642-1651) the most important was the Diggers, whose participants believed that God has created this world indiscriminately so it is not necessary to mend walls and barriers which separates man from man and man from society. The world is growing into single community so it is necessary to tear of the obstacles of exploitation. From $16^{\text {th }}$ to $20^{\text {th }}$ centuries in a number of west European countries feudalism was ascended by capitalism with the speedy development of Technology, Natural science and production. The manual work of labors are replaced by machinery, mills and mines, the energy of human mind and muscles engendered energy of steam engine subsequently electricity. Within the hectic span of two or three centuries; Technology and natural science and production are getting novelty by developmental forces of capitalism at unprecedented rate. Despite the rapid progress rate that ever had in history, the rate of exploitation became the counterpart of capitalism as it was under the slave owning and feudal system. Karl Marx and Freidrich Engels stated the history of all hitherto existing society is the history of class struggles. ${ }^{3}$ So capitalism was marked by the essence of apathy, inhumanity and found to be at daggers drawn for man's comfort. Capitalism itself heralded the dawn of socialist doctrines and became evident for the strong protest of people against existing social order. The term socialist was first used by French socialist Claude-Henri de SaintSimon. He called for "New Christianity" or "the religion of engineers." Social teachings, modern science and industrialization are combined in new religion to generate a society that would cater the taste of every one by providing basic human necessities. In England the Anglican ecclesiastical figure Frederick Denison Maurice in collaboration with Charles Kingsley initiated Christian socialist movement by 1840 . Liberation theology gained strength among Roman Catholic Theologian in Latin America by 1960. In Britain Christian socialist movement confederate with British labor party. Karl Marx and Freidrich Engels stated what the capitalist class produces, above all, is its own gravediggers ${ }^{4}$.

The basic notion of socialism was the idea of Humanism---respect and concern for man, real democracy, equality, justice, tolerance and peace. In forties of the $19^{\text {th }}$ century, Karl Marx (1818-1883) and Frederick Engels (1820-1895) commenced painstakingly their work in Germany. By the time capitalism had gained strength like growth of cancer in a body in Europe and North America. It seemed that the bourgeois, who lay down the law to private property and exploitation extended to such an extent of endless rule. But to the thesis of capitalism there appeared anti-thesis in 1848, the Communist Manifesto prophetically by Marx and Engels. They proved that a new socialist society by revolution was emerging without wage-slavery, class war, tyranny, despotism, inequality and injustice. The social force acted as right wing behind socialist revolution was the Proletariat, extremely rebellious and revolutionary class against capitalism.

Marx and Engels stated Let the ruling classes tremble at a communist revolution. The proletarians have nothing to lose but their chains. They have a world to win $^{5}$. Marx was

\footnotetext{
${ }^{3}$ Marx - Engels Manifesto of communist party Volume 1, p.35

${ }^{4}$ Ibid, p.46

${ }^{5}$ Ibid, p. 65
} 
a philosophy student at Berlin University where he came under the sway of idealism of G. W. F. Hegel. The factors that influenced upon Marx's philosophy are French socialism, German philosophy and British economics. Marx propounded inverted philosophy to Hegelian tradition. According to Hegel, History is the evolutionary process of world-spirit to the attainment of self -knowledge To Marx, world-spirit is dominated by economic forces. Life is not determined by consciousness, but consciousness by life ${ }^{6}$. For Hegel reality is another face of rationality; to Marx, reality is materially and economically determined. For Hegel the process of history is the struggle between nations; to Marx, history is a class struggle over economic interest. For Hegel freedom is consisted in man's consciousness man is most independent when he knows himself to be determined by the absolute idea throughout. ${ }^{7}$ Further Hegel cited world history is progress in cognition of freedom, progress which we must know in its necessity $^{8}$. Marx appreciates freedom of will and freedom of activity therefore looks forward to proletariat revolution. Winston Churchill stated "the inherent vice of capitalism is the unequal sharing of blessings; the inherent virtue of socialism is the equal sharing of miseries ${ }^{9}$. The objective of this study is to highlight the perception of socialist vision as modern and enlightened nations. The subject is very important in literature, philosophy also in sciences. Many authors have promoted this topic as a road to well-being, many others made this topic insurmountable barrier but I deal the topic from different angle, for instance I quoted the basic features of renowned scholars, philosophers, authors and theorists like Karl Marx, Fredrech Engels, G.W.F. Hegel and ideas from the book Man and Society translated from Russian text edited by D. Chesnokov and V. Karpushin. The topic may enable us to understand the particular purpose of the New Man in the New Society. Moreover, research paper will help to clarify that New Man is living without illusions, knowing that desires of liberty and happiness, evil of destructiveness and failure exist side by side. The New Man will seek for his own salvation and radical independence-a Socialist State verily.

\section{Replacement of Capitalism}

Man is a social animal and social life is based upon labour. Human life would cease to exist without labour and productive activity. The vital element in social development is the production of material wealth. Productive faculty requires two things: labour of men and objects of labour. Labour power turned into definite relations with production. The relations of production, disposition and distribution of productive wealth bank upon the ownership. For instance in the case of private ownership the owner never toil and bruised in productive labour but captured the lion's share. In capitalism production means social products, yielding commodities easily available to society. Production stands for social actions rather than isolated actions. Such as under feudalism the peasant alone is destined to cultivate flax, spinning wheel, the hand loom and developed it into yarn, cloth and garments. Under capitalism all the operations are being done under capitalism mechanically which coalesces hundreds of enterprises employing

\footnotetext{
${ }^{6}$ Marx and Engels, German Ideology, p.15

${ }^{7}$ Hegel, the Logic of Hegel, p.283

${ }^{8}$ Hegel, Vorlesungen uber die philosophie der weltgeschichte, i. Leipzig, p.40

${ }^{9}$ www.brainyquote.com
} 
thousands of people. Capitalism established international market, united the entire world into economic internationalism. The foundation of the League of Nations and the United Nations is a proof of international consciousness. In $19^{\text {th }}$ century capitalism was entering into its last phase of imperialism, a chief supporter to internationalism. Capitalism par excellence imperialism became the ground reality for onerous and ruinous courses for all states of colonial slavery globally. Few references are made here: Heinous atrocities committed by the Belgians in the Congo, same bigotry and exploitation was done in India under British rule, whites in Kenya and South Africa relinquished birthright of natives and usurped their land. It has been estimated that 1.5 millions of whites owned about 280 millions of acres of land while 5.5 millions of Negroes having only 27 millions of acres of land.

In 1924 Leonard Woolf stated "out of the total revenue estimated about 2 million pounds, the government of Kenya spent $£ 44000$ pound on prisons, $£ 37000$ pound on education the policy of government was to favor about 10000 Europeans at the expense of 36000 Asian and 25000 Africans. All the best land was reserved for Europeans and the native is on the road which leads to economic slavery. ${ }^{10}$

In southern Rhodesia (currently Zimbabwe), Libya, Egypt, Africa, Burma, Ceylon and Singapore handful of whites reduced majority of natives to the position of slavery Englishman had a monopoly to attain highest possible profits. To accomplish the task the imperialists escalated the exploitation for both proletarian (natives, workers, slaves) and those of colonial and dependent nations. Capitalism...... Has left remaining no other nexus between man and man than naked self-interest, than callous "cash payment."11 Modern imperialism began in 1884 with the scramble for Africa. All European nations vied with each other to vanquish as much territory as they could. Between 1884 and 1914 France possessed 4 million square miles with 50 million inhabitants, Great Britain possessed more than three million square miles with 57 million inhabitants and Germany possessed one million square miles with 15 million inhabitants of Dark Continent. During $19^{\text {th }}$ century Russia prolonged its territory up to Central Asia, Japan established its territory up to Korea and China, Italy extended its territory up to Ethiopia. In 1935 white people controlled 85\% around the globe for the motives of Lease-holds, financial control, traffic control, raw material control, condominium and protectorates.

During the $20^{\text {th }}$ century, there was an outbreak of two world wars among the imperialist powers for national interest as bone of contention. As a result of two Great wars (World War I\&II) in 1922 The Irish Free State was set up, Iraq became independent in 1932, Pakistan and India got independence in 1947, Burma got independence in 1948, Indonesia became independent in 1949, Morocco, Sudan and Tunisia became independent states in 1956, Ghana became an independent country in 1960, Uganda and Tanganyika became independent states in 1962, Kenya, Malaysia and Nigeria became independent states in 1963, Zambia, Malawi and Tanzania emerged as independent countries in 1964, Angola became independent in 1975 and Zimbabwe was declared as

\footnotetext{
${ }^{10}$ Political theory, V.D.Mahagan, p.869

${ }^{11}$ Marx and Engels, Manifesto of the communist party, pp. $37-38$
} 
an independent state in 1980. The above mentioned states freed themselves from the colonial slavery to gain economic independence.

The first historic mission of working class in capitalism rather imperialism is to organize a revolutionary party as a defender of their everyday economic interest. Second historic mission of working class is to tarnish private ownership of means of production and bring them under control of state as a primogenitor and repository of the interest of masses. On the eve of imperialism a socialist revolution was ripening in Russia. To fulfill its missions, the theory of Karl Marx worked in venture with Lenin (1870-1924) as the theory of scientific Socialism, Marxism-Leninism. The C.P.S.U. central committee's theses stated these forms and methods have acquired international character. The experience gained in the Great October Socialist Revolution is an inexhaustible treasure-store of theory and practice of revolutionary struggle, a model of scientific strategy and tactics. ${ }^{12}$ Lenin not only developed the revolutionary theory to defy the challenge of imperialism but also drafted the "constructive strategy" and implemented the plans for reform, recovery and relief motives. Lenin's analysis of imperialism conveyed a message that capitalism was growing as a worldwide phenomenon transforming the globe into third world. Lenin predicts that the world proletariat will crop up to palmy days. Russia, on October $25^{\text {th }}, 1917$ the Lenin's Bolshevik party made a way the capitalist ruled. V. I. Lenin stated the land of Soviet is a torch of international socialism and an example to all the working people. ${ }^{13}$

In March 1919, modern communist movement was organized in Europe, Asia, Africa and America. Whoever is the leader performs the deeds at the prompting decree of the whole community. V. I. Lenin sets the general line of principles for Marxism-Leninism To be linked to the people. To live in the thick of their life. To know their mood. To understand them. To know everything about them. To be able to approach them. To win their absolute trust. Not to create a gap between leaders and led, between the vanguard and the whole army of labour ${ }^{14}$. All socialist countries are different from each other regarding size, shape, population, language, historical traditions, national culture, machinery of state power and constitution etc. But their common interest is same i.e. socio-economic system to raise living standards and speed up industrialization, to dart their glory in the economic competition with capitalism. V. I Lenin we are now exercising our main influence on the international revolution through our economic policy. The struggle in this field has now become global. Once we solve this problem, we shall have certainly and finally won on an international scale. ${ }^{15}$ The socialist system laid down its foundation upon principles of respect for national sovereignty, fraternal mutual co-operation and assistance. For the purpose of economic co-operation socialist countries---U.S.S.R, German democratic republic, Poland, Bulgaria, Rumania, Mongolia and Czechoslovakia build up council for mutual economic assistance (CMEA) in 1960. The tasks of council are co-ordination of national economic development plans, extensive trade, joint construction and scientific assistance, technical assistance,

${ }^{12} 50^{\text {th }}$ Anniversary of the great October socialist revolution, Moscow, 1967, pp. $8-9$

${ }^{13}$ V.I. Lenin collected works, vol 26, p.472

${ }^{14} \mathrm{~V}$.I. Lenin collected works, vol 44, p.497

${ }^{15}$ V .I. Lenin collected works, vol 32, p.437 
granting credits at low rate interest, specialization and co-operation in production. Socialist countries do not repress or segregate others smaller socialist states but to speed up the process of aggrandizement.

\section{Economic Decisive Factors in Capitalism}

The capitalist countries create and maintain the sort of political and economic environment in which success of one country means the failure of another, and vice versa. Division of labour between capitalist countries grounded on the enslavement of debilitated countries by strong ones to uphold imperialist power and to recede exacerbating their economical and cultural development. The author of The Fundamentals of scientific socialism highlighted the ideas of K. Marx and F. Engels within its pale, the gain of one state is the loss of the other. ${ }^{16}$

The capitalist economy is based on Laissez Faire principle. State-monopoly intervene the system to control, plan and program the economy. To accomplish the assigned strategy state monopoly assembles centrally administrated bodies and organizations which plans short-and long-term programmes, plans and scopes. Eventually every capitalist runs on his/her own firm with his/her own private interest. Gradually and ultimately capitalist society develops in a "free market" in unplanned way. Variably each private owner seeks his/her own benefit irrespective of welfare of society and whole economy so the free market is the engine that runs the whole economy. The market is the linker and connects different owners with one another. The market shows demand supply relation, if the product is in short supply demand would be high, the price automatically goes up. If the product is in good supply demand would be low the price goes down. The state regulation played vital role and takes the following initiative to increase demand of product: broad advertisement, the sale of durables on credit, speedily alterable mode in fashion, sales of undesirable goods at lower prices periodically etc. The excruciating encumbrance befell on taxpayers, whose income shapes the state budget. The government utilizes the state budget to finance its anticrises measures, which hold the enlargement of state order, particularly military orders to monopolies; the purveyance of economic aid (free grants and subsidies) to monopolies, basically those who are in dire economic straits. State monopoly can increase or decrease the extemporaneous development of capitalism but cannot do away the inhuman nature of imperialism, free market, effects of consumerism and competition.

\section{Economic Decisive Factors in Socialism}

Socialist economy is a centralized planned economy. The state stands for the great benefactor of Homo sapiens. The state unites all producers in unison of single economy. In the initial stages of socialism or primarily in the period of Transition from capitalism to socialism the prevalent mode of economy is private producer (enterprises and firms) that eliminates the feature of direct planned economy due to market spontaneity. Thus state hastens the development in right direction through organized strategies. The state

\footnotetext{
${ }^{16}$ Marx and Engels, selected works, vol I, p.495
} 
by law owns trade and money along with financial and trading organizations established by the bourgeois. The socialist enterprises are organized in two ways: via state trade (the state regulates the market by nationalization and municipalization the capitalist trade), via co-operative trade (which displace the role of private retailers.

State property includes major sectors: the bank, foreign and home trade, means of transport and communication, enterprises of heavy industry, the land with its mineral resources, forests, water and so on. In socialist state two types of socialist property emerged state enterprises (factories, agricultural enterprises) co-operative enterprises (collective farms of peasants and consumer co-operative.

Both systems are guided under direct assistance of state. The socialist state ousted he capitalist regime by applying economic measures, by selling goods at lower cost prices, with lower circulation costs and of better quality and assortment.

\section{The Threats of Neo-Colonialism}

The imperialist powers are trying to revamp in colonialism to curb socialism. Neocolonialism is a system of ideological measures to control economic, social, cultural progress of socialist states and to retard it. Indeed most Afro-Asian, Latin American countries are now independent but still they found themselves in clutches of imperialist countries. The greater part of economy i.e. factories and natural resources are dominated and regulated by imperialist monopolies. Another reason of neo-colonialism is so called "economic grant" given to the socialist countries by imperialist powers. This foreign grant has a clear cut purpose: to fix and strengthen their economic positions in socialist countries and to make their economic development as obedient puppet. Imperialist powers build up pressure to infringe upon the national sovereignty recipient countries to destabilize them. The economic grant is the neo-colonialist policy to show great regard for the economic welfare of socialist countries but trying to de-escalate newly-liberated countries. Another policy of neo-colonialism is "collective colonialism" rampant today to ransack Asian, African and Latin American nations. The establishment of the organization of American states (OAS), Central Treaty Organization (CENTO), and Southeast Asia Treaty Organization (SEATO) are the political alliances for old packages in NEW DEAL.

For the representatives of Communist and worker's Parties in Moscow, the demand of our epoch is to rid our planet completely of the curse of colonialism. Destroy its last centers and prevent its revival in new, camouflaged forms. ${ }^{17}$ The imperialist authoritatively imposed oppressive military expenditures using socialist territory to establish military bases for waging war against national liberation movement internationally. About 450 American bases are found on foreign territories. The quintessential enlightenment of neo-colonialism is U.S imperialism. The main proponent of U.S colonial expansion is the U.S dollar. The U.S foreign investment brings in profits twice as high as those in the U.S which accelerate the rate of dollar in international market. The American senator J. Williams Full Bright stated the great

${ }^{17} 50^{\text {th }}$ Anniversary of the great October socialist revolution, Moscow 
society has become a sick society....Both in our foreign affairs and in our domestic life we convey an image of violence....America has become a symbol of violence. ${ }^{18}$ The socialist countries accumulated more than two-thirds of the population of capitalist world; produce about $20 \%$ of the output of their manufacturing industry, $3 \%$ of machinery and $5 \%$ of metal produced in the non-socialist world. The annual per capita income of U.S.A in 2013 was $\$ 42,433$ as it is comparable to socialist countries like in USSR, in China $\$ 11,850$ and in Germany $\$ 45,687$

Thomas R. Adam Imperialism, notably U.S imperialism, was and continues to be the main enemy of the national liberation movement. ${ }^{19}$ The further tactic used by neocolonialist is "divide and rule." They create discrimination on part of social groups, tribes and religious communities. The onus forces of imperialism were behind the murders of Patrice Lumumba and Eduardo Mondale etc. Ceaseless endeavors are made to evict national liberation movement leaders for goods. V. I. Lenin stated There are diverse forms of dependent countries which, politically, are formally independent but in fact, are enmeshed in the net of financial and diplomatic dependence. ${ }^{20}$

\section{Conclusion}

A close analysis of this two antagonistic systems, leads us to the following conclusions:

Firstly socialism ennobles social welfare of all and sundry by fostering the primal elements of education, health, employment, high labor productivity etc on the basis of equal opportunity. On the contrary capitalism promotes deep economic inequality, anarchy, irremediable unemployment, mass poverty, illiteracy above all low labor productivity.

Secondly under socialism, relations of co-operations and mutual assistance are knit on fundamental principle of social property. Therefore the discrimination between property and labor, between masters and workers is annulled permanently. This creates classless society. On the other hand, in capitalism few capitalists own immense wealth and enjoy the fruits of labor produced by the biggest part of the world i.e. proletariat. The majority of working class is oppressed and suppressed by the exploiting minority which leads to class consciousness and class conflict. Marx stated the proletariat created the material means of ennobling labor itself and of multiplying its fruits to such a degree as to make general abundance possible. ${ }^{21}$

Thirdly socialism produces humanitarian and fraternal relation in society. The slogan "One for all and all for one" is the driving force of socialist society. For instance, capitalism is the history of colonialism, imperialism, racialism, chauvinism and individualism. The slogan "Man to man is a wolf" is the driving force of the capitalist society.

\footnotetext{
${ }^{18}$ The New York Times Magazine, August 201967

${ }^{19}$ Thomas R. Adam, Modern Colonialism, 1955

${ }^{20}$ V.I. Lenin Collected Works, vol. 22, p.263

${ }^{21}$ The People's Paper, London, 1854
} 
Fourthly the socialist state ensures the happiness for all members of society. Humans are happy because their interest, requirement and basic necessities are fulfilled by the system. Majority of people in the capitalist system are not happy because socioeconomic forces rip them apart. They feel insecure, uncertain and pessimistic about their future.

Fifthly socialism imparts the air of true democracy, expands the scope of human freedom just because of incentives of non-profit. Every member of society will work according to his/her ability and receives according to his/her needs. We are acquainted that Man is a species being. The full-fledged image of species is comprised in its lifeactivity. Therefore underneath socialism diverse skills are found (labors by hand and by brain) which is diametrically proportional to their wages. Such a system arose productive activity to electrifying level. While capitalism disfavors the spirit of democracy "give and take" the capitalist society is based upon competition and impoverishment.

The beacon light for socialism Karl Marx had a clear vision to be crowned over capitalist system. Socialism is "goal directed" phenomenon but at present socialist states have no remedy to the present apathetic chaos.

As the gulf between the U.S.S.R and the U.S.A widened, it exasperated the situation. The U.S.S.R, the Chinese communist, the countries of Eastern Europe had patrimonial right to support socialism while non-socialist nation led by the U.S.A are strong barrier to socialist expansion. The key to understand and assess the essence of modern age is unapproachable; the hopeful factors are given by socialism. To suggest reforms is useless without implementation. As it is evident from a number of statements by specialists that our earth could accommodate a comfortable living for more than 10 thousand million people if the current scientific, technical and productive achievements were vested in right directions. Although world's population at present is not much more than 7 thousand million people instead of above mentioned fact humans are deprived off basic necessities of living

On the basis of above stated facts we conclude that the vision of new man and new society is comprehensible only if the old motivational forces of profit and power are commuted by new forces of being, sharing, and understanding and if cybernetic revolt is substituted by new vitalizing humanistic spirit.

\section{Bibliography}

Brian R. Nelson Western Political Thought $2^{\text {nd }}$ edition: 1996 Singapore Florida International University Pearson Education Press, 330-333

Plato, Republic, 380 B.C Ancient Greece, 138

Old Testament, chapter 3

Karl Marx and Freidrich Engels, 1968 New York, Menifesto of the communist party, selected works vol I, international publishers, 35 
Marx and Engels, German ideology, 1932 Moscow

R. Kosolapov, Communism and Freedom, 1970 Moscow, Progress Publishers

G.W.F Hegel, Vorlesungen uber die philosophie der einleitung, Leipzig, 1930, 40

www.brainyquote.com/quotes/keywords/socialism.html, (accessed on 24-07-2016)

Karl Marx and Freidrich Engels, 1968 New York, Menifesto of the republic party, selected works vol I, international publishers

$50^{\text {th }}$ Anniversary of the great October socialist revolution, 1967 Moscow

V.I. Lenin collected works, vol 26, USSR 1917-1918, Progress Publishers , $5^{\text {th }}$ Russian edition, USSR 1917-1920, Progress Publishers , vol 32, USSR 1920-1921, Progress Publishers, 437

Translated from the Russian by G. Ivanov-Mumjiev-L. lempert and M. Saifulin, Fundamentals of scientific socialism, 1969 Moscow, Progress Publishers

$50^{\text {th }}$ anniversary of the great October socialist revolution, 1967 Moscow,

The American senator J. William Ful Bright, the New York Times magazine, August 20 1967

Thomas R. Adam, Modern colonialism, institutions and policies, 1955, New York Universities

V.I. Lenin collected works, vol 22, USSR 1915-1916, progress publishers, 263

Thomas R. Adam, Modern colonialism, institutions and policies, New York universities, 1955

The people's paper no.98, London, march 18, 1854

Karl Marx, economic and philosophic manuscript of 1844, 1932 Moscow, progress publisher 